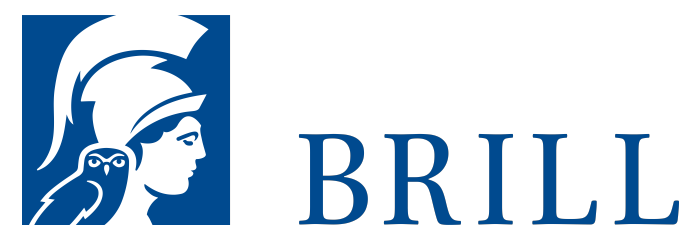

\title{
Das versteckte Bild
}

Zum Modellcharakter der kantischen

Gegenstandskonstitutionstheorie

Author: Carmen Taina Morscheck

Bildmodelle sind seit jeher in wahrnehmungs- bzw. bewusstseinstheoretische Untersuchungen eingegangen; die kantische Gegenstandskonstitutionstheorie ist bisher jedoch nicht in den Fokus einer bildtheoretisch ausgerichteten Studie geraten. Die Rekonstruktion eines > versteckten< Bildes, die in dieser Studie gelingt, beleuchtet insofern einen bisher übersehenen Aspekt der kantischen Theorie des Aufbaus der gegenständlichen Welt in der Kritik der reinen Vernunft. Kernstück des Buches ist der Aufweis, dass die kantische Theorie eine mediale Instanz beinhaltet, die den Ort einer Bildoberfläche einnimmt und eine strukturelle Affinität zu ihr aufweist: die Anschauungsmannigfaltigkeit. Indem die Anschauungsmannigfaltigkeit mithilfe von Stilkategorien der formalen Ästhetik stilistisch analysiert und anschließend in die Nähe zu konkreten Bildoberflächen gesetzt wird, tritt das >versteckte< Bild gleichsam anschaulich hervor. Mit ihrem innovativen Brückenschlag zwischen Kant-Interpretation und bild- und kunsttheoretischer Untersuchung stellt die Studie sowohl einen systematischen Beitrag zur Kant-Forschung als auch einen Beitrag zur aktuellen bildtheoretischen Debatte dar.

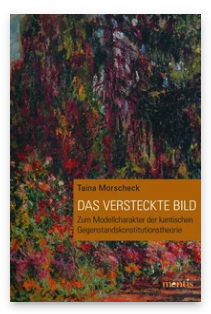

Pages: 234

Seiten

Language:

German

Subjects:

General,

Philosophy

Publisher: Brill | mentis

E-Book (PDF)

Released online:

13 Dec 2016

ISBN: $978-3^{-}$

95743-865-2

List price

Paperback

Publication date:

13 Dec 2016

ISBN: 978-3-

95743-049-6

List price 
For more information see brill.com

Order information: Order online at brill.com +44330 333 0049 | customerservices@brill.com Submission information: brill.com/authors

Titles published by Brill | Fink, Brill | mentis or Brill | Schöningh: +49(o)715413279216| brill@brocom.de 